media) from India, three Red Deer (Cercus elaphus of $q$ ), British, two White-tailed Gnus (Connochates gmu of of), bred in Holland; a Ruffed Lemur (Lemur varizs) from Madagascar, deposited; a Red-crested Pochard (Fuligula nufina o) from India, purchased.

\section{ASTRONOMICAL PHENOMENA FOR THE WEEK 1888 NOVEMBER 4-IO.}

(FOR the reckoning of time the civil day, commencing at Greenwich mean midnight, counting the hours on to 24 , is here employed.)

\section{At Greenwich on Novinber 4}

Sun rises, 7h. $2 \mathrm{~m}$. ; souths, I Ih. $43 \mathrm{~m} .40^{\circ} 9 \mathrm{~s}$. ; sets, r $6 \mathrm{~h} .26 \mathrm{~m}$. : right asc. on meridian, 14h. $40^{\circ} 3 \mathrm{~m}$.; decl. $15^{\circ} 36^{\prime} \mathrm{S}$. Sidereal Time at Sunset, 19h. $23 \mathrm{~m}$.

Moon (New on November 4, oh., and at First Cuarter November Io, 16h.) rises, 7h. I $3 \mathrm{~m}$. ; souths, I $2 \mathrm{~h}$. I $8 \mathrm{~m}$.; sets, I 7 h. I $2 \mathrm{~m}$. : right asc. on meridian, I5h. I4 $5 \mathrm{~m}$.; decl. $13^{\circ} 20^{\prime} \mathrm{S}$.

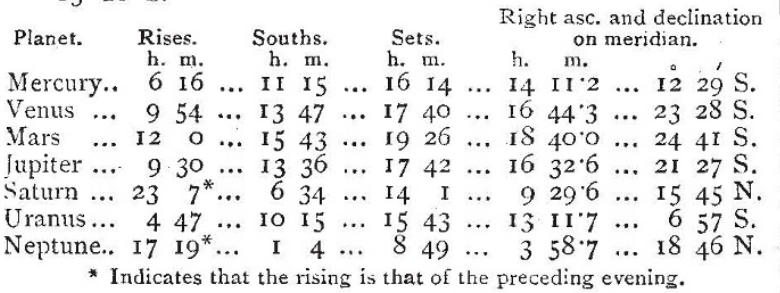

Occultation of Star by the Moon (visible at Greenwich).

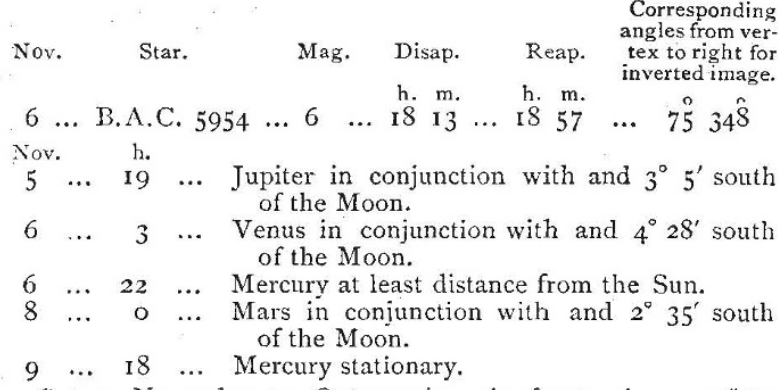

Saturn, November 4.--Outer major axis of outer ring $=40^{\prime \prime} \cdot 7$ : outer minor axis of outer ring $=9^{\prime \prime} 7:$ southern surface visible.

\section{Variable Stars.}

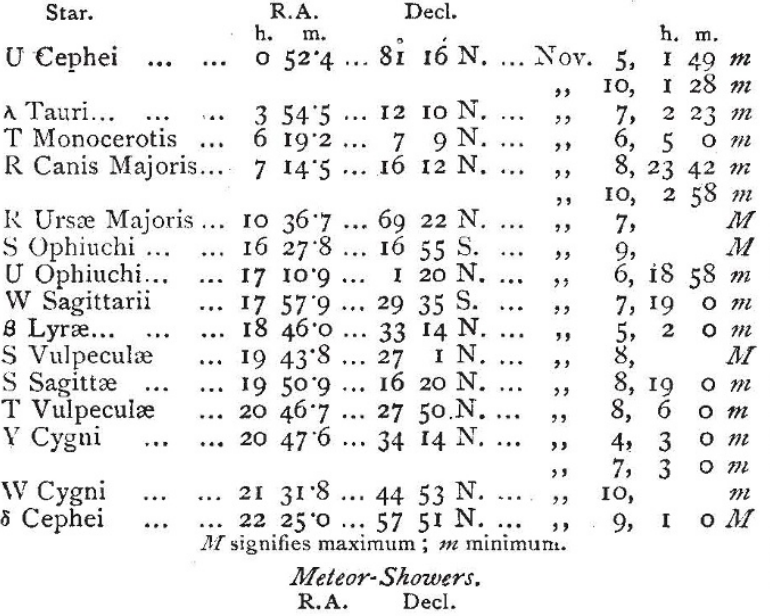

Near $\gamma$ Camelopardalis... $54 \ldots 7$ i $\quad 5 . \quad \ldots \quad$ Swift.

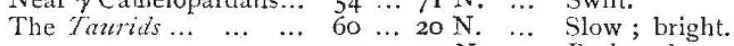
$350 \ldots 52 \mathrm{~N} . \ldots$. Rather slow.

\section{GEOGRAPHICAL NOTES.}

In some notes embodying the results of his own observations, contributed to the Mittheilungen of the Hamburg Geograptrical Society, Dr. H. Lindemann throws some light on the physical geography of the interior of Heligoland. He points out that the island is protected on the east from the action of the sea by a long and narrow sand-dune, about $\mathrm{I} \frac{1}{4}$ mile distant. The gradual disappearance of this British possessirn, Dr. Lindemann points out, is but partly due to the action of the sea. This is especially the case with the western side, where the strength of the waves is much greater. The chief factors in wearing down the island are the heavy rainfall, the variations in the weather, and the dissolving power of the frost; all these causes effect the disintegration of the stones and the denudation of the land. The results can be seen retter at work on the eastern side of the island, for the strata and the inclination of the Oberland are towards the north-east, and all the water conseguently flows that way. The eastern side is largely planted with potatoes, and the gradual disappearance of these potato-fields gives us a tolerably good basis on which to calculate the sinking of this side of the island. There is now nothing remaining of a potato-field which only eighty years ago measured 80 metres, and another field, 25 metres broad, has been reduced within the same period to 3 metres. In old maps we find an ancient cemetery on the eastern side of the Oberland, which had to be removed to ifs present position. These causes, but, above all, the direction in which the strata lie, produce the different aspect of the eastern and western sides. The eastern cliff is mostly uniform and perpendicular; the western side offers a splendid and varied example of the invasive powers of the sea, with its many inlets, caverns, and chiselled pillars now separated from the main rock. From a comparison with the measurements taken in 1845 , Lindemann finds that the western cliff had receded about 7 feet in the last forty years, or at the rate of about 2 inches a year. The Unterland was joined to the dune by a stone jetty, called the Waal, as recently as the seventeenth century. This Waal formed a kind of semicircular harbour, open on the north and south sides. If we take Geern's map, we find the place of the old northern harbour occupied then by green pastures and meadows. But this has all been swept away; the sea carried most of the jetty towards the Unterland and the dune. The destruction of the breakwater had the effect upon the mainland that the Unterland, against which the masses of stone were driven, was gradually so greatly increased that new rows of houses could be built upon the beach.

IT is stated that contracts have been entered into in America for the construction of two steamers intended for an expedition to the Antarctic regions, which is being organized by Mr. Henry Villard. The officers and scientific staff of the expedition will all be Americans and Germans, as the enterprise is stated to be in great part supported by Hamburg money. The expedition will start from New York, and itg object will be mainly the exploration of the South Shetlands, South Orkneys, South Georgia, and the Poovel Islands. This expedition seems to be independent of that to be sent out by the German Government under the conduct of Dr. Neumayer.

Mr. Joseph Thomson has returned from Morocco in compliance with an urgent telegram from the British East African Company. Mr. Thomson will probabiy start immediately for Mombassa, and we have reason to believe will be intrusted with a very important mission to the interior.

\section{PREIIMINARY NOTE ON THE ANATOMY AND PHYSIOLOGY OF PROTOPTERUS ANNECTENS}

\section{Introduction.}

$\bigcirc$ WING to the generosity of Prof. Wiedersheim, I have recently had the opportunity of making some observations on the structure and mode of life of Protopt. mes. Although I can at present only give a few brief notes on the subject, some points have already proved so interesting, that it has seemed worth while to give an abstract of my results up to the present time, leaving a detailed description until a later date.

I was fortunate enough to be present in Freiburg at the end of last June when a quantity of fresh material arrived. This was procured direct from the Gambia, owing, in the first instance, to 